\title{
Variability of Pestalotia spp, with special reference to the effect of media, temperature and light on their growth, sporulation and spore germination
}

\author{
A. N. IBRAHIM, M. M. SATOUR, E. M. ELAKKAD \\ Dep. of Agric. Botany, Fac. of Agriculture, Al-Azhar Univ. \\ and Instit. of Phytopathological Research, Min. of Agric. \\ Egypt
}

Ibrahim A. N., M. M. Satour, E. M. El Akkad: Variability of Pestalotia spp. with special reference to the effect of media, temperature and light on their growth, sporulation and spore germination. Acta Mycol. 12 (1): 141-151, 1976.

Potato dextrose and mango leaf extract agar media were found to be the most favourable for mycelial growth of Pestalotia spp. The optimum temperature for growth and sporulation was $25^{\circ} \mathrm{C}$. Continuous light promoted mycelial growth and continuous darkness retarded it. The maximum percentage of germinated spores was obtained under intermittent daylight conditions.

Germination of Pestalotia spores occurred at various stages of maturity. The percentage of germination decreased with the increase of the storage period in the host tissues, and after 12 months spores lost their viability completely. Mycelia in the same infected tissues, however, were found to be still alive and capable of producing new fructifications till 18 months. Morphological characters of the fungus, and mode of spore germination were also investigated.

\section{INTRODUCTION}

Pestalotia spp. have been isolated from spotted leaves of mango (Mangifera indica L.) for the first time in Egypt (S a to ur, I b r a h i m, E 1 A k k ad 1974). Nine species have been recognized, where P. leucothoës 316 and $P$. conigena 497 proved to be the most pathogenic isolates.

Their growth, sporulation and spore germination as influenced by media, temperature and light were studied in the present investigation. In addition, the viability of spores and mycelia in the diseased tissues stored for more than one year was also studied. 


\section{MATERIALS AND METHODS}

P. leucothoës 316 and P. conigena 497 were isolated from spotted mango leaves collected from Inshas-Sharkiya, tested for their pathogenicity and maintained on potato dextrose agar medium.

The radial growth of the isolates as recorded on 7 agar media namely malt extract (MA), mango leaf extract (MO), potato dextrose (PDA), Brown's (B), Czapek's (Z), Richard's (R) and Waksman's (W). Five Petri dishes were prepared for each variable and plates were incubated at $26^{\circ} \mathrm{C}$ for 7 days.

Sporulation was estimated by the determination of the amount of spore masses, distribution on the colony, and range of their size.

Spore germination took place on sterile glass slides in Petri dishes. The plates were kept moist by placing moistened filter paper underneath the slide. Small holes, $6 \mathrm{~mm}$ in diameter, were cut in the filter papers to facilitate the microscopic examination of the spores without removing the slides from the plates. About 200 spores were examined at five field microscope, $\times 160$.

\section{RESULTS AND DISCUSSION}

Effect of media on radial growth, sporulation and growth characters of Pestalotia species

Natural media showed better growth than the synthetic ones. PDA was the best, followed by mango leaf extract, and then malt extract. The synthetic media in descending order were Waksman's, Brown's, Richard's and Czapek's respectively. Results are presented in Table 1 and illustrated by Figure 1.

\section{Table 1}

Effect of different media on the linear growth of Pestalotia species

\begin{tabular}{|c|c|c|}
\hline \multirow{2}{*}{ Media } & \multicolumn{2}{|c|}{$\begin{array}{c}\text { Mean colony diameter }(\mathrm{mm}) \\
\text { after } 7 \text { days }\end{array}$} \\
\hline & P. conigena 497 & P. leucothoës 316 \\
\hline PDA & 86 & 75 \\
\hline Malt extract agar & 73 & 55 \\
\hline Mango leaf extract & 80 & 68 \\
\hline Waksman's agar & 52 & 56 \\
\hline Brown's agar & 50 & 51 \\
\hline Richard's agar & 24 & 33 \\
\hline Czapek's agar & 10 & 26 \\
\hline
\end{tabular}


Fig. 1. Vegetative growth of $P$, leucothoës 316 and $P$, conigena 497 on the different media

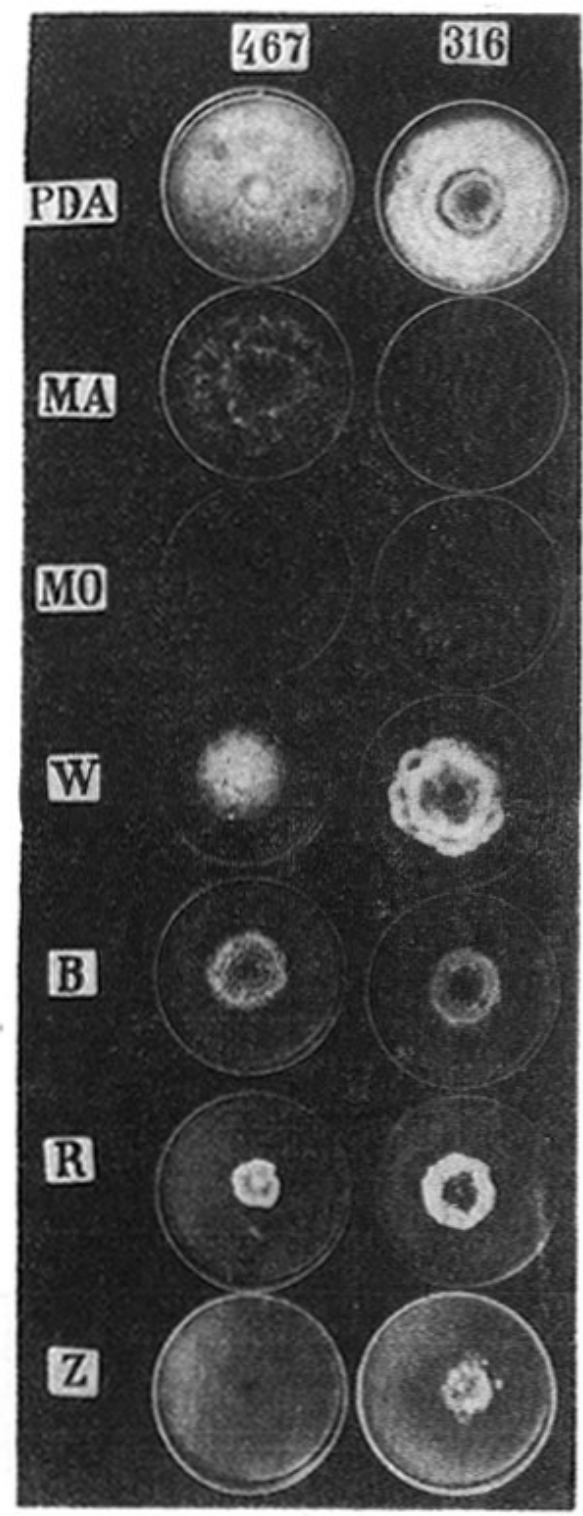

With regard to sporulation and growth characteristics, remarkable differences were observed (Table 2 and Fig. 1). P. leucothoës did not produce spores at all on mango leaf extract and Czapek's agar media. On the other madia, however, both species sporulated well. This may be due to the effect of certain nutritional requirements. 


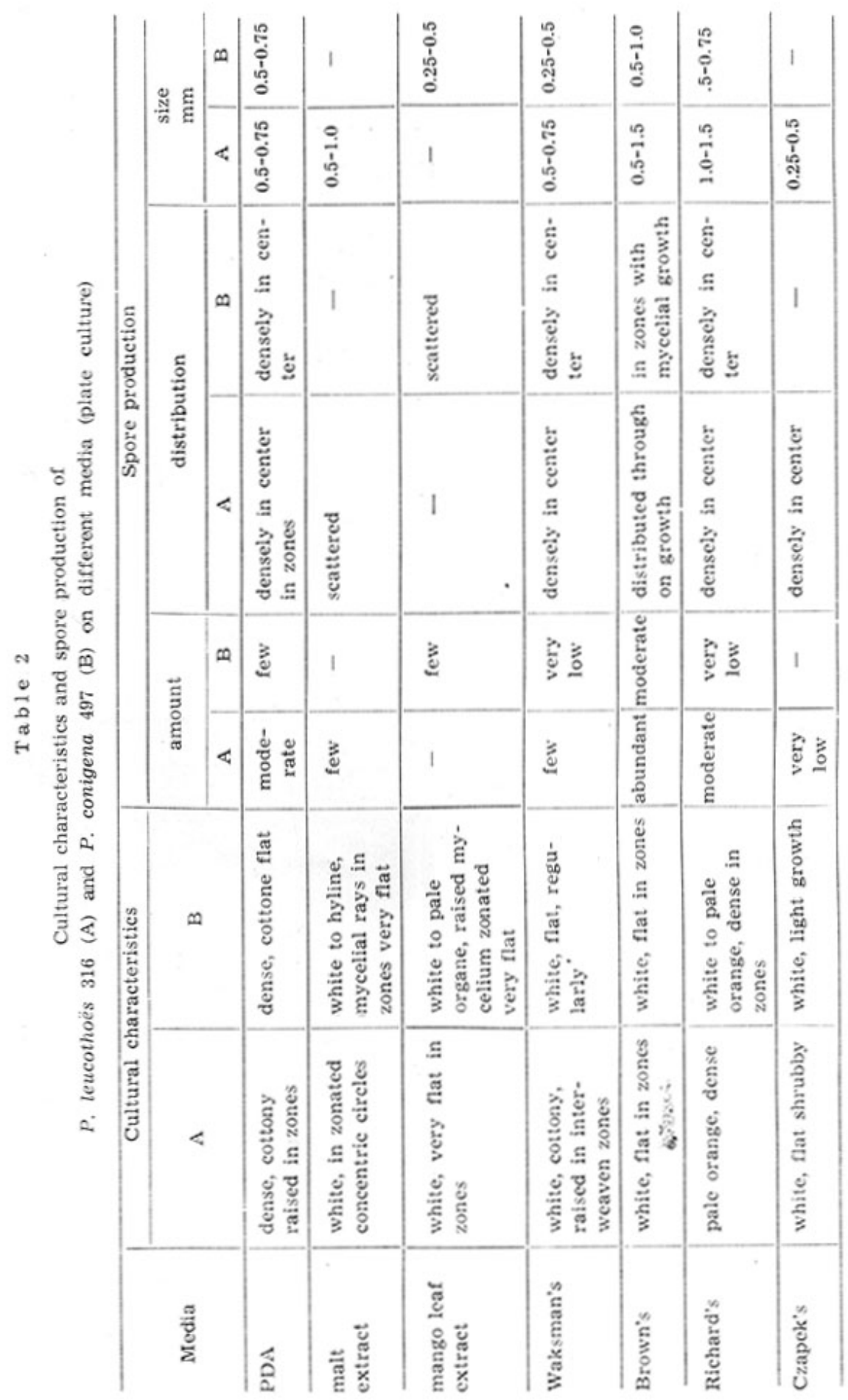


Effect of temperature on radial growth and spore germination of Pestalotia species

This experiment was carried out on PDA medium only. P. leucothoës 316 and $P$. conigena 497 gave the least radial growth at 8 and $35^{\circ} \mathrm{C}$. No growth occurred at all at $40^{\circ} \mathrm{C}$. and the optimum temperature was found to be in the order of $25^{\circ} \mathrm{C}$.

The minimum temperature for spore germination and length of germ tube for both species was below $15^{\circ} \mathrm{C}$., the maximum was $35-40^{\circ} \mathrm{C}$., and the optima for spore germination and length of germ tube for both species was 25 and $30^{\circ} \mathrm{C}$. respectively (Table 3 ). These results are in agrement with those reported by Sarker (1960), and Tandon and Lal (1964).

\section{Table 3}

Effect of temperature on the radial growth, spore germination and length of germ tubes of $P$. leucothoës 316 and $P$. conigena 497 on PDA medium

\begin{tabular}{c|c|c|c|c|c|r}
\hline \multirow{2}{*}{$\begin{array}{c}\text { Tempe- } \\
\text { rature } \\
\left({ }^{\circ} \mathrm{C}\right)\end{array}$} & $\begin{array}{c}\text { P. leucothoës 316 } \\
\text { mean colony } \\
\text { diameter } \\
(\mathrm{mm})\end{array}$ & $\begin{array}{c}\text { spore } \\
\text { germination } \\
(\%)\end{array}$ & $\begin{array}{c}\text { germ } \\
\text { tube } \\
(\mathrm{mm})\end{array}$ & $\begin{array}{c}\text { mean colony } \\
\text { diameter } \\
(\mathrm{mm})\end{array}$ & $\begin{array}{c}\text { spore } \\
\text { germination } \\
(\%)\end{array}$ & $\begin{array}{c}\text { germ } \\
\text { tube } \\
(\mathrm{mm})\end{array}$ \\
\hline 8 & 6 & 0 & 0 & 5 & 0 & 0 \\
15 & 46 & 16 & 70 & 53 & 12 & 64 \\
20 & 60 & 88 & 200 & 61 & 84 & 173 \\
25 & 88 & 94 & 281 & 81 & 90 & 231 \\
30 & 81 & 92 & 338 & 78 & 81 & 290 \\
35 & 8 & 27 & 32 & 10 & 18 & 44 \\
40 & 0 & 0 & 0 & 0 & 0 & 0 \\
\hline
\end{tabular}

Effect of light on radial growth, sporulation and spore germination of Pestalotia species

Continuous light produced the best radial growth for both species tested. However, alternating and intermittent light conditions proved to be better than continuous darkness which retarded the radial growth.

With respect to sporulation, exposure to the light is required for satisfactory sporulation. Unexposed cultures produced few spore masses. Alternating light and darkness promote spore production, while under continuous light spore production was abundant (Table 4).

In order to study the transmission of light effect within the same colony, the following technique was used: PDA medium in a test tube $(25 \times 1 \mathrm{~cm})$ with one side constriction was inoculated in the middle with the fungus inoculum. Only one-half of the test tube was covered wtih black paper, then the tube was exposed to continuous flurescent light 
for 8 days (Fig. 2). Results (Table 5) indicated that in both species, the radial growth of the one-half exposed to light was faster than that of the unexposed half. The data also indication that although light increased

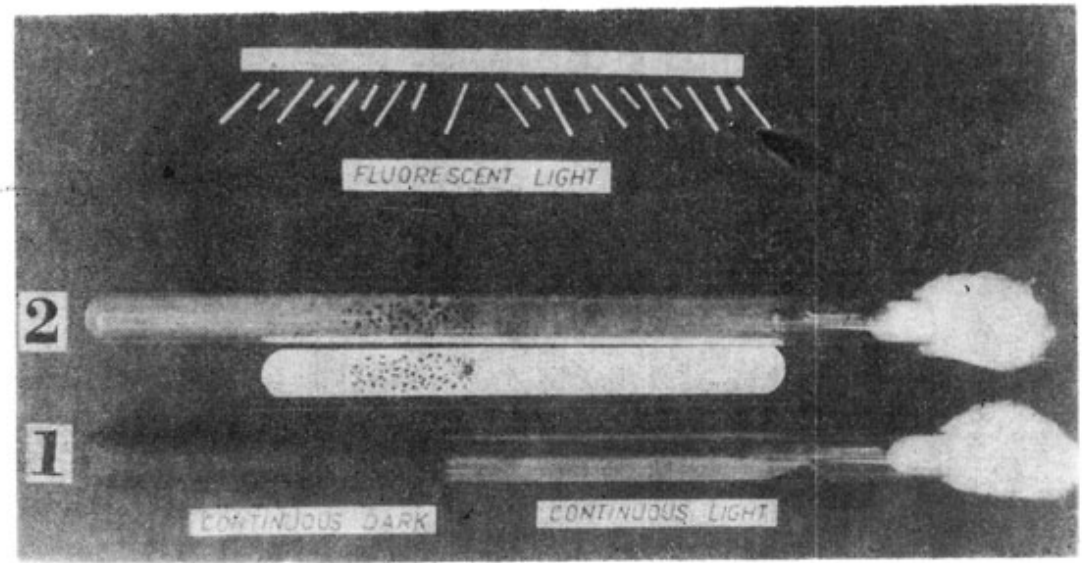

Fig. 2. A tube devised for studying the effect of continuous light and darkness on the growth and sporulation of Pestalotia spp.

1 - the tube at the start of the experiment; notice the dark paper and the constriction, 2-the tube after incubation and removal of the black paper (below this tube a diagrammatical drawing for light effects)

Table 4

Effect of various light conditions on the radial growth, and spore production of Pestalotia leucothoës 316 (A) Pestalotia conigena 497 (B) on PDA medium

\begin{tabular}{|c|c|c|c|c|c|c|}
\hline \multirow{3}{*}{ Light conditions } & \multirow{2}{*}{\multicolumn{2}{|c|}{$\begin{array}{l}\text { Mean co- } \\
\text { lony dia- } \\
\text { meter } \\
(\mathrm{mm})\end{array}$}} & \multicolumn{4}{|c|}{ Spore production } \\
\hline & & & \multicolumn{2}{|c|}{$\begin{array}{l}\text { amount and size } \\
(\mathrm{mm})\end{array}$} & \multicolumn{2}{|c|}{ distribution } \\
\hline & A & B & A & B & $\mathrm{A}$ & $\mathrm{B}$ \\
\hline Continuous light & 82 & 86 & $\begin{array}{c}\text { abundant } \\
0.5-1.0\end{array}$ & $\begin{array}{c}\text { moderate } \\
0.1-0.3\end{array}$ & $\begin{array}{l}\text { distributed } \\
\text { in all colony }\end{array}$ & as in $\mathrm{A}$ \\
\hline $\begin{array}{l}\text { Continuous } \\
\text { darkness }\end{array}$ & 51 & 63 & $\begin{array}{c}\text { few } \\
1.0-2.0\end{array}$ & $\begin{array}{c}\text { few } \\
0.5-1.0\end{array}$ & distributed & as in $\mathrm{A}$ \\
\hline $\begin{array}{l}\text { Alternating, } 1 \mathrm{~h} \\
\text { light and } 23 \mathrm{~h} \text { dark }\end{array}$ & 70 & 73 & $\begin{array}{c}\text { moderate } \\
0.5-1.0\end{array}$ & $\begin{array}{c}\text { moderate } \\
0.1-0.5\end{array}$ & $\begin{array}{l}\text { densely in } \\
\text { center, in } \\
\text { zones }\end{array}$ & as in $\mathrm{A}$ \\
\hline $\begin{array}{l}\text { Intermittent day } \\
\text { light }\end{array}$ & 72 & 70 & $\begin{array}{c}\text { moderate } \\
1.0-1.5\end{array}$ & $\begin{array}{c}\text { few } \\
0.5-1.0\end{array}$ & $\begin{array}{l}\text { densely in } \\
\mathbf{7 5 \%} \text { of old } \\
\text { growth }\end{array}$ & $\begin{array}{l}\text { densely in } \\
30 \% \text { of old } \\
\text { growth }\end{array}$ \\
\hline
\end{tabular}


the amount of spore masses, the unexposed part stimulated the production of spore masses of larger size. These results are in agreement with those obtained by Grover and Karve (1963) and M anda$\mathrm{h}$ ar (1970), but disagreed with those reported by Yusef and Alla m (1967) who stated that growth of Pestalotia was not stimulated by light.

Spore germination of Pestalotia species was retarded under continuous darkness. Alternating light and darkness, and continuous light however, favoured spore germination, and the maximum percentage of spore germination for both isolates was obtained under intermittent daylight condition (Table 6).

Table 5

Effect of continuous light and darkness on the same colony of $P$. leucothoës 316 and $P$. conigena 497 on PDA medium

\begin{tabular}{|c|c|c|c|c|}
\hline \multirow[b]{2}{*}{ Species } & \multicolumn{2}{|c|}{ Continuous darkness } & \multicolumn{2}{|c|}{ Continuous light } \\
\hline & $\begin{array}{l}\text { mean co- } \\
\text { lony dia- } \\
\text { meter } \\
(\mathrm{mm})\end{array}$ & spore production & $\begin{array}{l}\text { mean co- } \\
\text { lony dia- } \\
\text { meter } \\
(\mathrm{mm})\end{array}$ & spore production \\
\hline $\begin{array}{l}\text { P. leucothoës } \\
\quad 316\end{array}$ & 59 & $\begin{array}{l}\text { sporulation about } \\
75 \% \text { of colony, } \\
\text { spore masses } \\
\text { dense, } 0.5-2.0 \mathrm{~mm} \\
\text { in diam. }\end{array}$ & 98 & $\begin{array}{l}\text { sporulation masse } \\
\text { distributed in all } \\
\text { colony, } 0,20-0.75 \mathrm{~mm} \\
\text { in diam. }\end{array}$ \\
\hline $\begin{array}{l}\text { P. conigena } \\
497\end{array}$ & 46 & $\begin{array}{l}\text { sporulation about } \\
30 \% \text { of colony, } \\
\text { spore masses } \\
\text { dense, } 0.5-1.0 \mathrm{~mm} \\
\text { in diam. }\end{array}$ & 83 & $\begin{array}{l}\text { sporulation about } \\
60 \% \text { of colony, } \\
0.1-0.5 \mathrm{~mm} \text { in } \\
\text { diam. }\end{array}$ \\
\hline
\end{tabular}

Table 6

Effect of light conditions on spore germination of P. leucothoës 316 (A) and $P$. conigena 497 (B) on PDA medium

\begin{tabular}{l|c|c|c|c}
\hline \multicolumn{1}{c|}{ Light conditions } & \multicolumn{2}{|c|}{$\begin{array}{c}\text { Spore } \\
\text { germination } \\
(\%)\end{array}$} & \multicolumn{2}{|c}{$\begin{array}{c}\text { Length of germ } \\
\text { tube } \\
(\mu \mathrm{m})\end{array}$} \\
\cline { 2 - 5 } & A & B & A & B \\
\hline Continuous light & 75 & 61 & 298 & 272 \\
Continuous darkness & 33 & 19 & 249 & 151 \\
Alternating 1 h light and 23 h dark & 80 & 72 & 225 & 174 \\
Intermittent day light & 88 & 78 & 440 & 396 \\
\hline
\end{tabular}




\section{Viability of Pestalotia}

a) Maturity of spores:

Results (Table 7) showed that immature spores could germinate, however, percentage of germination was found to be less than those of mature ones.

b) Longevity of spores:

Spores of $P$. leucothoës 316 were collected from dried mango leaves stored at room conditions for various periods up to 12 months, and tested for germination. Results showed that spore germination decreased during

Table 7

Mean percentage of spore germination of $P$. leucothoøs 316 on PDA medium

\begin{tabular}{l|c}
\hline Maturity stages & Germination (\%) \\
\hline Nature spores (colored cells with long setulae) & 92 \\
Immature spores (subhyaline cells with short setulae) & 78 \\
Immature spores (hyaline cells with very short setulae) & 60 \\
\hline
\end{tabular}

storage. Slight reduction was observed after one and three months of storage (from 94 to 87 and $81 \%$ respectively). A remarkable decrease was recorded after 6 months $(19 \%)$, and spores completely lost their viability after 12 months storage. A similar result was obtained with 4. cucumerina, where condiospores completely lost their viability after t months storage under natural conditions ( $\mathrm{b} \mathrm{rahim}$. A bdel-Hak Mos ta f a 1974).

2) Viability of the fungus within the infected leaves:

The mycelial viability was tested by placing the infected leaves in noistened chambers. This revealed that the mycelium was present within the storage leaves of mango is still alive and capable of producing new acervuli on infected tissue till the end of 18 months. The fungus attacked the uninfected tissues of the leaves, and caused new spots. Furthermore, the old acervuli produced new spore masses.

Morphological characters of Pestalotia and mode of spore germination:

On PDA medium, the hyphae were hyaline, narrow, thin-walled $2-4 \mu \mathrm{m}$ in width, frequently septate, and profusely branched.

There is considerable uniformity among the structure of the fructifications in vivo (S a to ur, I brahim, El Ak kad 1974), and considerable variation in vitro. Pseudo-pyenidia without clear true ostioles, formed on PDA medium (Fig. 3), were either emerged or superficial on the medium. The spores erupted in black, moist and light of the masses. 
Spore aggregation projecting from the fruiting bodies took various shapes, and ranged between 100 to $2000 \mu \mathrm{m}$ in diameter. Despite this variation in vivo and vitro, the genus Pestalotia should remain as it is in the order Melanconiales. This conclusion is confirmed by the fact that the whole classification system of imperfect fungi is based mainiy on fungal fruiting bodies as encountered in nature (B is by 1953, and T a l b ot 1971). The fungal conidia were formed exogenously. This is in

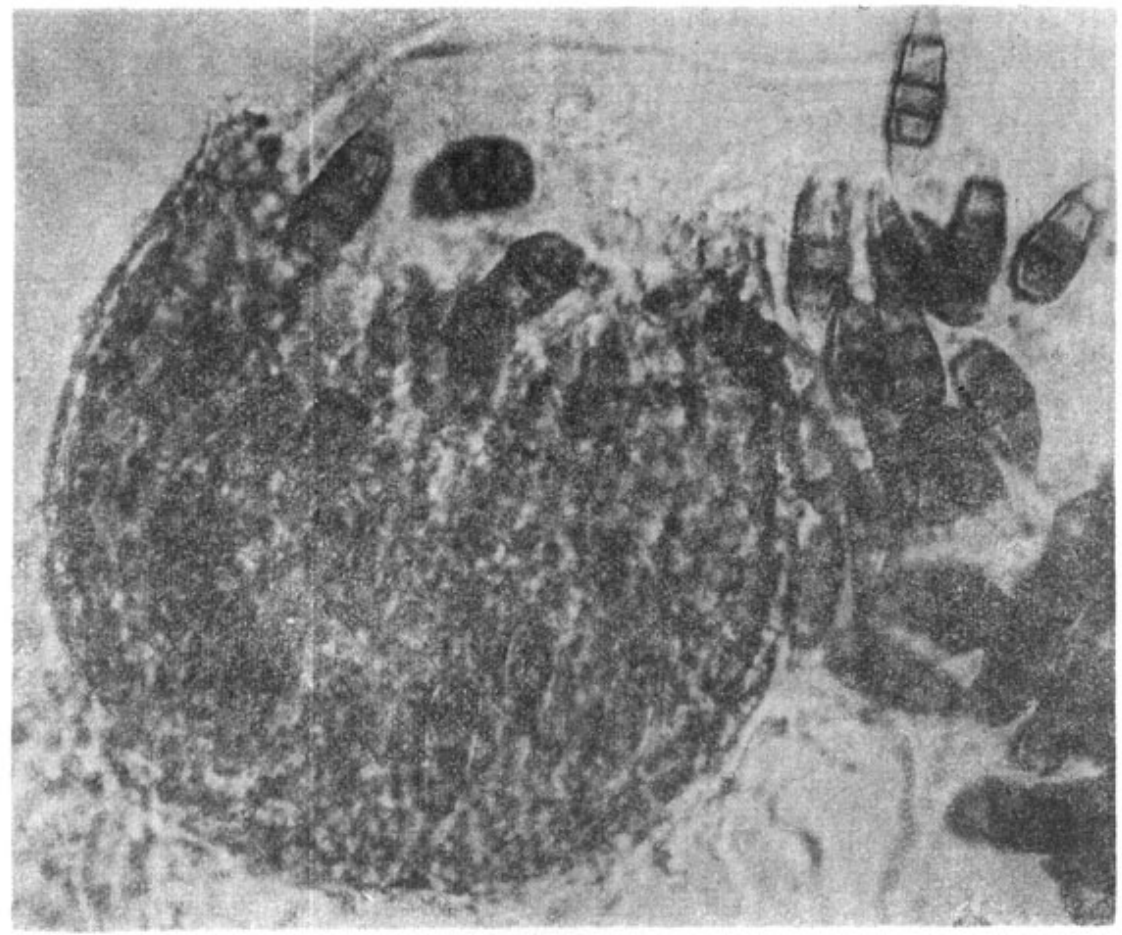

Fig. 3. A pseudopycnidium without true ostiole of $P$. leucothëos 497 formed on PDA medium

contrast with the data of Don Ritchie (1960), who described the endogenous conidial production.

The stages of exogenous conidial production, on PDA medium were also observed. The tip cell of the fertile hypha increased in size and when it reached it a typical shape and size, four septen were laid down forming five cells. The ultimate cell to the conidium produced 2-5 terminal appendages, setulae. Setulae achieved their maximum length after the conidium had reached its full size. 
The mature conidiospores in the final form were colored, and measurable characters did not show any variation with age of culture. Generally, conidia, were fusiform, straight or rarely slightly curved, 5 cells crowned with 2-5 simple setulae. The terminal cells were hyaline, while the intermediate cells were variably colored, contrasted or strongly contrasted. The upper two of the intermediate cells were brown to black, while the third is light brown. The spore pedicels were hyaline, simple, attached to the base of the conidia. Conidial biometric measurements were essential to identify the species.
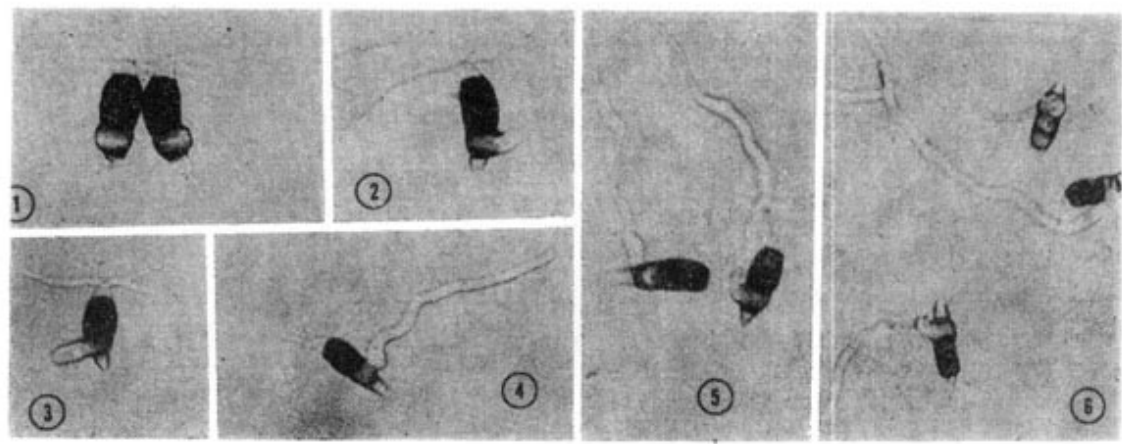

Fig. 4. Stages of spore germination of Pestalotia leucosthëos 497

1 - the basal dark colored cell become more spherical in shape, 2 -the germ tube pushed out, 3,4-the germ tube elongates rapidly, and 5, 6-the germ tubes branched at once

In water culture, the fungus formed well-terned, gelatineous black spore balls, $750-2000 \mu \mathrm{m}$ in diameter. In contrast, the fungus did not produce well-developed mycelia in this culture.

Spored germinated always from the basal dark colored cell. This cell, swelled and became spherical, the wall burst, then one germ tube with lighter color pushed out. The germ tube enlarged and branched, sometimes, branched as soon as it appeared (Fig. 4).

\section{REFERENCES}

B is by G. R., 1953, An Introduction to the Taxonomy and Nomenclature of Fungi. 2nd. ed. Commonw. Mycol. Inst. Kew, Surrey, 143 p.

Don Ritchie, 1960, Endogenous conidium production in Pestalotia. Mycologia 52: 655-657.

Grover R. K. and Karve A. D., 1963, Induction by light of sporulation in Pestalotio theae Sawada. Canad. J. Bot. 41: 569-571.

Ibrahim A. N., Abdel-Hak T. M. and Mostafa M. M., 1974, Survival of Alternaria cucumerina (Ellis \& Evereh.) Elliot. The causal organism of leaf 
spot disease of cucurbits. Acta Phytopathol. Acad. Sci. Hung. (under publication).

M a ndahar C. L., 1970, Effect of light on sporulation of Pestalotia theae Sawada. Sci. Cult. $39: 467-468$.

Sarker A., 1960, Leaf spot disease of Mingifera indica caused by Pestalotia mangifera Butl. Lloydia 23 (1): 1-7.

Satour M. M., Ibrahim A. N. and ElAkkad E. M., 1974, A leaf spot disease of mango incited by a species of Pestalotia. The 1st. Cong. of The Egyptian Phytopathol. Soc.,- Cairo March. Abst. 37.

Talbot P. H., 1971, Principles of Fungal Taxonomy. The MacMillan Press, London. $274 \mathrm{p}$.

Tandon R. N. and Lal B., 1964, Pathological studies of Pestalotia bicolor Ell. et Ev. causing leaf spot disease of Diospyros peregrina. Pros. Natn. Acad. Sci. India Sect. B, 34: 343-349, R. A. M. 45: 3188 (1966).

Yusef H. M. and Allam M. E., 1967, The effect of light on growth and sporulation of certain fungi, Mycopath. Mycol. Appl., 33: 81-89. 